\title{
Soils of Yucatan: Effect On The Growth Of The Habanero chili Plant (Capsicum chinense)
}

\author{
Rodríguez-Buenfil IM1 ${ }^{1 *}$, Ramírez-Sucre MO $^{1}$ and Echevarría-Machado I ${ }^{2}$ \\ ${ }^{1}$ Center for Research and Assistance in Technology and Design of the State of Jalisco AC (CIATEJ), Mexico \\ ${ }^{2}$ Center Scientific Research of Yucatan (CICY), Mexico
}

Submission: June 15, 2017; Published: June 29, 2017

"Corresponding author: Rodríguez-Buenfil IM, Center for Research and Assistance in Technology and Design of the State of Jalisco AC Southeastern Unit, Mérida, Yucatán, México, Email: irodriguez@ciatej.mx

\section{Mini Review}

Leptosols are the most common soils in the world (12\%). This is also the case in Mexico (24\%) and in the state of Yucatán (80\%) The high spatial heterogeneity of Leptosol areas complicates agricultural development, agronomic experimentation, and transfer of agricultural technology; among other things- The state of Yucatán, in southeast Mexico, has an extensive territory of undulating topography, forming a karstic plain developed on a deep sequence of Cenozoic limestone layers. Calcareous bedrock and the subhumid climate have contributed to the formation of soils showing differences in depth, stone content, $\mathrm{Fe}$ and $\mathrm{Al}$ as residual material, and other chemical and physical soil properties. The soil mantle, composed mainly of weakly developed protosoils is highly variable [1].

The fruits of Capsicum chinense plants grown in the Yucatan Peninsula have a denomination of origin "Yucatán Peninsula habanero chili" from 2010 [2] based on their unique characteristics of flavor, aroma, pungency, color and shelf life; these are due to the special conditions in the region, which are suggested to be due to the particularities of the soils in which they are cultivated.

For cultivation of $C$. chinenese three main types of soil are used (K'áankablu'um (red soils), Box lu'um (black soils) or ch'ich 'lu'um (stony soils), this classification does not consider however, it is local knowledge that the stony soil is limited in micro and macronutrient contents, as well as poor water retention capacity. These soil properties can cause different types of stress to the plants, such as stress due to potassium $(\mathrm{K})$ deficiency or water stress.

The interaction of the soil with the plant affects the development of the fruit, since the amount of nutrients, water and salinity in the soil has a significant effect on the quantity and size of fruit, whereas other studies have shown a direct relation of the content of some secondary metabolites with the same factors. However, when plants are cultivated the variety of factors affecting development cannot simply be reduced to the presence or absence of a nutrient or lack of water, the soil structure is complex and variant, although nutrition can be corrected by chemical methods, other soil parameters do not.

In one study [3], Twenty-eight laboratory tests were performed on samples from 24 soils At least $50 \%$ of the soils were silt loam, with low apparent density $\left(0.58-0.82 \mathrm{~g} \mathrm{~cm}^{-3}\right)$, high porosity (71-74\%), from neutral to moderately alkaline, very slightly saline, and very high OM contents ( $>6 \%$ ). Of the soils, 54 $\%$ were rich in $\mathrm{N}(>0.25 \%), 67 \%$ in $\mathrm{P}\left(>11 \mathrm{mg} \mathrm{kg}^{-1}\right)$ and $92 \%$ in $\mathrm{K}$ $(>0.6 \mathrm{cmol}(+) 100 \mathrm{~g}-1)$; in $88 \%$ the CIC was high to very high (25$52 \mathrm{meq} 100 \mathrm{~g}-1), 100 \%$ were high in Ca $\left(>10 \mathrm{cmol}(+) \mathrm{kg}^{-1}\right)$ and $75 \%$ were medium to high in $\mathrm{Mg}\left(1.3-5 \mathrm{cmol}(+) \mathrm{kg}^{-1}\right.$ More than 60 $\%$ were marginal in Fe ( 2 and $>1.0 \mathrm{mg} \mathrm{kg}^{-1}$, respectively). These results suggest that the soils in the state of Yucatán are highly heterogeneous in their physical and chemical characteristics.

In another study [4], yields of habanero chili fruits showed the importance of applying high doses of $\mathrm{N}_{2} \mathrm{P}_{2} \mathrm{O}_{5}$ and $\mathrm{K}_{2} \mathrm{O}$ to the soil and the availability of sufficient water in the soil solution for this species. Similar results were reported with red and green chilies [5]; with paprika [6] and with $C$. chinense sweet [7]; They indicate that the yield decreases as the nutrition or the usable moisture is reduced, this as a detrimental physiological response to stressful nutritional and water conditions, indicating that the translocation of assimilates towards the fruits decreases as the deficit of water.

Analyzing the two main types of soil in Yucatan (black and red), the relation between the edaphic characteristics and the bacterial and fungal community structures in these two kinds of Leptosol [8], the results revealed that Black Leptosol (BlaS) had 
a higher content of calcium carbonates, organic matter, nitrogen, and phosphorus than Red Leptosol (RedS). The most outstanding difference in the bacterial community structure between BlaS and RedS was that while in BlaS Actinobacteria was the most abundant phylum (43.7\%), followed by Acidobacteria (26.9\%) and Proteobacteria (23.6\%), in RedS the bacterial community was strongly dominated by Acidobacteria (83\%).

Nitrogen, along with phosphorus, are the nutrients that most limit crop productivity. In addition, it is known that nitrogen, potassium and water deficit can affect the synthesis of capsaicinoids in the fruits of habanero chile $[9,10]$. The presence of different nitrogen sources in the three soil types of Yucatan can lead to significant changes in plant growth and development. For example, exogenous nitrate has been [11], and regulates transcript levels of a nitrate transporter of high affinity in this species [12]. Nitrate per se stimulates leaf cell expansion $[13,14]$ and has a very significant effect on the metabolism of C, especially by stimulating the synthesis of acids.

On the other hand, the presence of an organic source of nitrogen in the soil, as in the case of amino acids, can lead to completely different morphological changes than those caused by the inorganic nitrogen source. For example, glycine inhibited the growth of the primary root of habanero chili, but stimulated the formation and elongation of root hairs and induced a significant accumulation of starch granules at the root apex [15].

According to the characteristics of the leptosols in interaction with the characteristics of the crop, that it does not tolerate excesses of moisture and does not present a high nutritional demand, is that partly the favorable adaptation can be explained, and consequently, the particular characteristics presented by the Habanero Chile from the Yucatan Peninsula.

\section{References}

1. Bautista F, Díaz-Garrido S, Castillo-González M, Zinck JA (2005) Spatial Heterogeneity of the Soil Cover in the Yucatán Karst: Comparison of Mayan, WRB, and Numerical Classifications. Eurasian Soil Science 38(1): S81-S88.

2. Diario Oficial de la Federación (2010) Órgano del Gobierno Constitucional de los Estados Unidos Mexicanos. Declaratoria General de Protección de la Denominación de Origen Chile Habanero de la Península de Yucatán.
3. Borges-Gómez L, Moo-Kauil C, Ruíz-Novelo J, Osalde-Balam M, GonzálezValencia C, et al. (2014) Soils used for habanero chili production in Yucatán: predominant physical and chemical characteristics. Agrociencia 48(4): 347-359.

4. Borges-Gómez L, Cervantes Cárdenas L, Ruiz Novelo J, Soria Fregoso M, Reyes Oregel V, et al. (2010) Capsaicinoidsin Habanero Pepper (Capsicum chinense Jacq.) undervarious humidity and nutritionalconditions. Terra Latinoamericana 28(1): 35-41.

5. Wierenga PJ, Hendrickx JMH (1985) Yield and quality of trickle irrigated chile. College of Agriculture and Home Economics, Mexico.

6. Pire R, Colmenarez YO (1994) Extracción y eficiencia de recuperación de nitrógeno por plantas de pimentón sometidas a diferentes dosis yfraccionamientos del elemento. Agron Trop 46: 353-369.

7. Jaimez RE (2000) Crecimiento y distribución de la materia seca en ají dulce bajo condiciones de déficit de agua. AgronomíaTropical 50(2): 189-200.

8. Estrada-Medina H, Canto-Canché BB, De Los Santos-Briones C, O’Connor-Sánchez A (2016) Yucatán in black and red: 'Linking edaphic analysis and pyrosequencing-based assessment of bacterial and fungal community structures in the two main kinds of soil of Yucatan State. Microbiol Res 188-189: 23-33.

9. Medina-Lara F, Pacheco-Arjona R, Ruiz-Lau N, Guzmán-Antonio A, Echevarría-Machado I, et al. (2008) Influence of nitrogen and potassium fertilization on fruiting and capsaicin content in Habanero pepper (Capsicum chinense Jacq.). Hortscience 43(5): 1549-1554.

10. Ruiz-Lau N, Medina-Lara F, Minero-García Y, Guzmán-Antonio A, Echevarría-Machado I, et al. (2011) Water deficit affects the accumulation of capsaicinoids in fruits of Capsicum chinense Jacq. Hortscience 46(3): 487-492.

11. Celis-Arámburo TJ, Carrillo-Pech M, Castro-Concha LA, Miranda-Ham ML, Martínez-Estévez M, et al. (2011) Exogenous nitrate induces root branching and inhibits primary root growth in Capsicum chinense Jacq. Plant Physiol Biochem 49(12): 1456-1464.

12. Santiago-Antonio G, Lizama-Gasca MG, Carrillo-Pech M, EchevarríaMachado I (2014) Natural variation in response to nitrate starvation among varieties of habanero pepper (Capsicum chinense Jacq.). Australian Journal of Crop Science 8(4): 523-535.

13. Walch-Liu P, Neumann G, Bangerth F, Engels C (2000) Rapid effects of nitrogen form on leaf morphogenesis in tobacco. J Exp Bot 51(343): 227-237.

14. Kiba T, Kudo T, Kojima M, Sakakibara H (2011) Hormonal control of nitrogen acquisition: role of auxin, abscisic acid, and cytokinin. J Exp Bot 62(4): 1399-1409.

15. Domínguez-May ÁV, Carrillo-Pech M, Barredo-Pool FA, Us-Camas RY Moreno-Valenzuela OA, et al. (2013) A novel effect for glycine on root system growth of habanero pepper. Journal of the American Society for Horticultural Science 138(6): 433-442.

\begin{tabular}{|l|}
\hline Your next submission with Juniper Publishers \\
will reach you the below assets \\
- Quality Editorial service \\
- Swift Peer Review \\
- Reprints availability \\
- E-prints Service \\
- Manuscript Podcast for convenient understanding \\
- Global attainment for your research \\
- Manuscript accessibility in different formats \\
( Pdf, E-pub, Full Text, Audio) \\
- Unceasing customer service \\
Track the below URL for one-step submission \\
https://juniperpublishers.com/online-submission.php \\
\hline
\end{tabular}

